\title{
Pembangunan Pertanian Berbasis Kecerdasan Masyarakat
}

\author{
Murasa Sarkaniputra
}

The goal and the orientation of long term Indonesian development are a just and prosperous society based on Pancasila. To reach this long run Indonesian development afore-mentioned can be conducted by several steps either that applied by old order, new order or that of reformation era. The vision of the development actually is nation and Character building. Contrary to the vision of Indonesian development that appear negative phenomena from the actors of Indonesian development above mentioned, for instance coalition, corruption and nepotism. To overcome the problems of Indonesian nation currently, this nation needs to develop community intelligence-based agricultural development.

Kata-kata kunci: pertanian, kecerdasan masyarakat, adil dan makmur.

Qasaran pembangunan dalam jangka dan makmur berdasarkan Pancasila." Untuk mencapai sasaran jangka panjang tersebut ditempuh dengan bertahap.Tahapan pasca revolusi fisik ditujukan untuk memelihara dan menjaga keutuhan NKRI, termasuk merebut Irian Barat, dan ini dapat dicapai dengan baik di bawah pimpinan Presiden Soekarno. Rencana Pembangunan Semesta Berencana Delapan Tahun yang disusun ditujukan untuk memandu pelayan publik dan masyarakat dalam membangun bangsa dan negaranya, "Nation and Character Building" . Sementara itu pergolakan politik di dalam negeri dan disusul dengan konfrontasi terhadap Malaysia,berakhir tragis di pertengahan 1960-an. Khaos terjadi pada tenggat tahun 1965/1966. Bangsa ini menjadi porak poranda karena konflik politik sedangkan ekonomi diterlantarkan. Tritura yang dikumandangkan oleh Angkatan 66, "Bubarkan PKI, Rombak Kabinet 100 menteri, Turunkan Harga" menjadi acuan untuk menggalang persatuan dan kesatuan bangsa: membangun manusia Indonesia seutuhnya berdasarkan Pancasila. Sementara itu kondisi khaotik berlanjut pada beberapa tahun berikutnya. Dalam tingkah laku organisasi kondisi khaotik biasanya diikuti oleh adanya naked emperor phenomena (Champan and Ward, 2002), yakni gejala tidak tahu malu dari para aktor pembangunan baik itu yang birokrat maupun yang termasuk usahawan.

Visi membangun manusia Indonesia seutuhnya berdasarkan Pancasila dirancang dalam pembangunan bertahap lima-tahunan yang kemudiannya disebut Rencana Pembangunan Lima Tahun (Repelita). Dalam kondisi khaotik di atas, pemerintah 
menebar mahasiswa untuk memasyarakatkan program BIMAS bersamaan dengan pembangunan institusi sosial dan ekonomi di perdesaan. investasi modal dalam negeri dan modal asing datang bertahap. Di bawah Presiden Soeharto, 1966-1996, laju pertumbuhan ekonomi meningkat dengan sangat berarti. Kelembagaan ekonomi perdesaan dipercepat pembangunannya, fokusnya pada swasembada pangan khususnya beras. Tercatat singkatan yang memasyarakat dan dikenal masyarakat seperti: BIMAS, INMAS, WILUD, BUUD, KUD, BRI-UD, dan UDKP. Tersebut belakangan adalah lembaga yang mirip seperti Saemaul Undong di Korea Selatan. Model ini terkesan sebagai pengembangan dari BPMD (Badan Pembangunan Masyarakat Desa) yang dibangun tahun 1950an di tiap kawedanan pada era kepemimpinan Presiden Soekarno.

Pendekatan yang serba sistem tersebut dinilai sangat berhasil terukur menurut surplus beras dalam tahun 1984. Surplus beras sebagianya digunakan untuk membantu negara-negara miskin Afrika dan meminjamkannya kepada negara-negara anggota Asean. Sementara itu kontrol terhadap pembangunan industri dan jasa terlalaikan. Tercatat adanya kebijakan yang memanjakan industri yang tua, mapan dan padat modal yang teronggok di kota-kota. Diduga jumlahnya hanya sekitar ribuan yang dikuasai oleh 300-an konglomerat,tapi mereka, yang berskala besar itu, menguasai ekonomi nasional. Bandingkan usaha kecil yang jumlahnya lebih dari 30 juta unit usaha.

Efisiensi dan efektivitas kerja industri padat modal yang bercorak multi-national corpo.ation (MNC) di atas terjebak pada kolusi antara birokrasi kekuasaan dan kroninya. Masyarakat menamakannya korupsi, kolusi dan nepotisme (KKN). Ini tentu saja tidak menjamin berlangsungnya good governance yang pada gilirannya melalaikan pemerataan pendapatan. Ketimpangan pendapatan antarwarga masyarakat terlalu tinggi. Begitu juga tidak meratanya kemajuan antar daerah dan antar wilayah. Ketika terjadi serangan dari pemain asing (strange operator) yang datangnya dan membentur sistem kepemerintahan yang rapuh kondisi ekonominya dan mentalitas pelakunya, maka terjadilah khaos.

Khaos babak kedua terjadi pada pertengahan 1997. Kondisi ekonomi, politik dan sosial menjadi porak poranda. Tak terjalin saling percaya mempercayai antarwarga masyarakat. Pembangunan ekonomi terganggu, pertanian dan perdesaan seakan lepas dari jangkauan kebijakan pusat dalam investasi real, malah terkesan terlalaikan. Produsi beras merosot, impornya melonjak setiap tahunnya. Petani merosot pendapatannya, lingkungan hidup terganggu, fasilitas air dan pengairan, pendidikan, kesehatan menjadi terbengkalai, pengangguran melonjak.

Indeks pembangunan manusia/Human Development Index (IPM/HDI) tergolong rendah yaitu, di urutan ke 110 pada tahun 2000-an. Rendahnya HDI menunjukkan rendahnya tingkat pendidikan dan kesehatan, tingginya kematian bayi di bawah setahun dan ibu melahirkan, serta rendahnya pendapatan per kapita.Kondisi tersebut semakin berbahaya bila arahnya menjadi negatif, yakni kefakiran berubah menjadi kekafiran. Kondisi khaotik inipun ditandai oleh adanya naked emperor phenomena. Yakni mereka yang bertanggungjawab atas khaos itu malah memposisikan diri sebagai yang tidak tahu malu. Hal ini harus dicegah karena rakyat akan bertambah sengsara. Bagaimana caranya? 


\section{Permasalahan Pokok}

Dari uraian kesejarahan secara singkat di atas dapat dicatat permasalahan yang multi-dimensional ini terkesan seakan bangsa Indonesia terjerat dan tidak akan dapat mampu bangkit membenahi masalahnya. Adakah pemerintahan baru versi pilihan presiden langsung oleh rakyat mampu mereformasi kemelut itu? Kalau dapat, dari mana kita memulainya ketika ukuran-ukuran konvensional: pertumbuhan ekonomi, inflasi, tingkat, bunga, dan nilai tukar rupiah menjadi mandul? Kita menengarai masalah pokok yang mempertanyakan tentang kemampuan Indonesia untuk melakukan pembangunan sekaligus dengan pertumbuhan ekonomi yang tinggi. Ini harus dicermati ketika kabinet baru dengan Presiden RI hasil pilihan langsung rakyat akan memulai kerjanya. Apa bedanya dengan kabinet coba-coba seperti tercatat sejak pemerintahan Habibie, Gus Dur, dan Megawati? Reformasi dalam hal apa yang harus segera diteruskan dan dipercepat pelaksanaannya?.

\section{Diagnosis}

Dari telaah teori khaotik (Chorafas, 1995., Conner, 1998), ketika ekonomi suatu Negara terlanda khaos, dan keporakporandaan itu begitu besarnya, maka acuan utama untuk mereformasikannya adalah menelaah kembali asal-usul keberhasilannya dan mengapa terjadi khaos (Sarkaniputra, 2004). Oleh karena itu kunci utama untuk reformasi adalah pada besarkecilnya kemampuan kabinet 2004/2009 untuk membangun kembali semangat pembangunan yang fokusnya pada segugus pertanyaan tentang bagaimana (a) memenuhi kebutuhan dasar, (b) menjamin kelancaran transportasi melalui pembangunan infrastruktur, dan (c) menegakkan kembali sendi-sendi adab pergaulan untuk berakad kerjasama usaha sesuai dengan tingkatan emosi dan spiritual masyrakatnya. Fokus pertanyaannya ialah pada bagaimana memadukan berbagai pendekatan yang menjamin terentaskannya ke tiga masalah pokok tersebut di atas.

\section{Analisis}

\section{Pemenuhan Kebutuhan Dasar}

Pasal 27 ayat 2 UUD (1945 dan yang diperbarui) menyebutkan bahwa "Tiaptiap Warga Negara berhak untuk memperoleh pekerjaan dan penghidupan yang layak bagi kemanusiaan". Mengikuti as Syatibi dan mengacu pada asas Pancasila dan UUD 1945 maka kebutuhan dasar dapat mencakup: (a) terpenuhinya pemeliharaan iman, (b) tercukupkannya pendidikan untuk setiap warga Negara, sehingga semakin cerdaslah warga bangsa itu, (c) tercukupkannya pelayanan kesehatan, kesempatan untuk menyatakan harga diri, lingkungan yang sehat dan terjamin kelestariannya, ketentraman, dan pertahanan Negara, (d) terpeliharanya keluarga yang sakinah, mawwadah, warahmah sehingga dari rumahtangga dengan ciri-ciri seperti ini akan dapat menjamin karsa positif bagi pembangunan bangsa, dan (e) tercukupkannya kebutuhan fisik untuk pangan, sandang dan perumahan serta harta yang kepemilikannya dijamin oleh hukum.

\section{Sarana dan Prasarana}

Untuk memenuhi kebutuhan dasar tersebut di atas diperlukan adanya berbagai instrumen kebijakan pembangunan yang mendorong percepatan pemulihan dari situasi khaotik kepada situasi yang kondusif bagi kelancaran mekanisme pembangunan 
di daerah, antar daerah, antar wilayah, dan antar Negara. Mengikuti Ball and Nijkamp, 2001, maka ada lima kendala (constraints) yang perlu dicermati untuk menjamin tercapainya uraian pada butir 2.1 yakni (i) piranti lunak (soft ware) berupa kemampuan manusia dan program-program yang menjamin keserasian dan keselarasan antar kegiatan ekonomi, (ii) piranti keras (hard ware) yang menjamin lancarnya mekanisme komunikasi fisik transportasi (darat, laut, udara), komunikasi informasi, (iii) piranti organsiasi (organization ware) yang mendukung kelancaran tugas-tugas admnistrasi Negara dalam rangka pelayanan kepada masyarakat, (iv) piranti finansial (financial ware) sebagai ukuran untuk kapabilitas dan kredibilitas suatu Negara yang berdaulat, dan ( $v$ ) kondisi lingkungan hidup (ecological ware) yang menjamin kelestarian pembangunan spiritual, sosial dan ekonomi suatu Negara. Dalam analisis peta-peta strategis maka pertanyaan tentang bagaimana menjadikan asset yang tak terukur diubah menjadi hasil yang terukur adalah fokus tematik yang harus dibahas dalam balanced scorecard (Kaplan dan Norton, 2004).

\section{Kebijakan}

Kebijakan pembangunan 2004-2009 harus dilandaskan pada kontrak politik ketika warga bangsa memulai tradisi baru dalam pemilihan presiden. Tingkah laku masyarakat yang terlihat pada kinerja elit politik harus juga menjadi pertimbangan utama. Karena di sinilah letak fenomena kemasabodohan mereka terhadap masalah bangsa yang dalam keadaan khaotik itu. Kontrak politik itu dapat mencakup: (a) kesanggupan pemerintahan hasil pilpres langsung untuk melakukan reformasi secara cermat, (b) kemampuan untuk memberdayakan masyarakat kecil /miskin/ fakir/ duafa, (c) memberantas $\mathrm{KKN}$, dan (d) melakukan pemerataan pendapatan yang adil.

Apabila keempat kontrak politik itu dapat disepakatkan oleh pemerintahan hasil pilpres langsung, kabinet 2004-2009, maka instrumen kebijakannya dapat mencakup: (a) reformasi $A P B N$ dan $A P B D$ yang dengannya alokasi sumberdaya dapat terfokus pada pemenuhan kebutuhan dasar sekaligus dengan pemerataan pendapatan serta investasi di sektor-sektor pendukung, (b) reformasi transasksi dan kontrak usaha yang didasarkan pada semangat spiritual dari warga bangsa. Artinya bahwa kecerdasan masyarakat/community intelligence harus menjadi sumber dari pertumbuhan dan kelestarian usaha, (c) reformasi fiskal yang setiap aktor usaha memperoleh insentif ketika mereka harus mengeluarkan zakat dan pajak sekaligus, (d) reformasi moneter yang mencakup kesamaan /kesetaraan perlakuan dalam menentukan fasilitas kredit baik yang dengan sistem konvensional/bunga maupun yang bersistem non-ribawi, dan (e) memberantas $K K N$ dengan berani dan konsekuen. Kelima kebijakan ini harus menjadi misi dari setiap kementerian dalam kebinet presidensial 2004-2009.

Misi ini harus dijabarkan ke dalam rencana strategis dan model-modelyang bertebar di tiap wilayah pembangunan yang diselaraskan dengan keragaman kecerdasan masyarakatnya itu. Keragaman dalam kemampuan mereka untuk mengatasi masalahnya sendiri akan lahir. Kemandirian dalam kaitan ini menjadi acuan bersama bagi warganya. Kemandirian mungkin dapat terwujud hanyajika kecerdasan masyarakat dijadikan sebagai basis pembangunan ekonomi. 


\section{Model Pembangunan Pertanian Berbasis Kecerdasan Masyarakat}

\section{Asumsi}

Diasumsikan bahwa sistem ekonomi nasional ditata menurut analisis di atas, dan oleh karena itu maka model harus mengacu pada karakter bisnis sebagai berikut. Pertama, pebisnis mampu membangun kembali kepercayaan dirinya bahwa bisnisnya itu memperoleh pelayanan yang sepadan dengan semangat membangun ekonomi nasional karena KKN diberantas dan peluang muncul ditekan serendah mungkin. Pelayan yang tidak tahu malu dan atau masa bodoh harus disingkirkan dari birokrasi pemerintahan. Kedua, adanya jaminan dari otoritas moneter dan perbankan bahwa masyarakat mendapat kebebasan untuk memilih kredit usaha dengan yang konvensional atau yang non-ribawi. Oleh karena itu fasilitasi untuk kedua sistem itu harus sepadan sesuai dengan permintaan masyarakat. Ketiga, adanya jaminan bahwa pungutan liar (pungli) dalam sektor pengangkutan dan perdagangan harus sama sekali ditiadakan. Ini dimaksudkan agar mark-up atas biaya yang akan menaikkan harga barang tidak boleh terjadi. Keempat, semua input produksi pertanian harus tersedia di tingkat petani di tempat mana pebisnis pertanian mengerjakan usahanya. Manipulasi dalam penyediaan input produksi pertanian yang merugikan rakyat banyak harus dianggap sebagai tindakan subversif. Pelakunya harus dihukum berat setimpal dengan kesalahannya.

\section{Model Implementasi Kecerdasan Masyarakat}

- Kecerdasan masyakat mencakup kecerdasan emosional, spiritual dan intelektual/brain. Ketiga dimensi kecer- dasan inilah yang membangun akal-budi manusia (human mind). Ini berarti nilai-nilai agama yang menjadi tradisi masyarakat, baik yang kini diakui adanya dan diterapkan dalam kontrak bisnis harus diteruskan, sedangkan yang luntur oleh pengaruh luar, harus dihidupkan kembali apabila itu menjadikan masyarakat merasa tenteram baik secara batin maupun lahirnya. Misalnya tentang sistem usaha berbagi keuntungan dan berbagi kerugian/mudharabah/ musyarakah yang konsisten dengan jiwa dari UU No. 2 Tahun 1960 tentang Pokokpokok bagi hasil harus benar-benar diterapkan yang disertai pelayanan yang mudah dan murah dalam kontraklakad bisnis pertanian dalam arti luas. Kebiasaan masyarakat untuk bekerjasama dan bergotongroyong harus dihidupkan kembali melalui kerjasama bagi hasil itu. Hal ini dijamin oleh undang-undang perkoperasian. Justru tradisi inilah yang menjamin kelestarian usaha terukur menurut tingkat keuntungan yang memadai yang terbagi menurut besarnya saham masing-masing anggota koperasinya. Apabila surplus hasil usaha bertambah cepat naiknya, maka pertumbuhan ekonomi daerah akan dipercepat pula. Bersamaan dengan ini maka pemerataan pendapatan akan dijamin oleh pertumbuhan ekonomi itu. Inilah yang disebut growth with equity.

\section{DNA-artificial Chromosom}

Berdasar atas uraian pada Bagian 1, 2 dan 3, maka dapat membentuk DNA-artificial chromosom untuk suatu akad bisnis yang khas untuk suatu masyarakat dan juga dapat diakomodasi oleh masyarakat lain dengan mengacu pada keragaman budaya, agama, tradisi, dan wilayah pengembangan usaha. Hal ini sebagai kias untuk menjadikan spirit usaha yang menjamin keserasian antara uhrawi dan jasmani apabila seseorang 
bermuamat dalam memenuhi kebutuhan hidupnya. Pemikiran ini terinspirasi oleh Choudhury, 1986, 1987, 1998a, 1998b. Dalam investasi syari'ah dikenal adanya empat spirit yakni: (i) setiap pelaku akad/ muakid sesia-sekata untuk berbagi untung dan rugi, (ii) mengusahakan komoditi yang halal dan toyib, (iii) mengeluarkan zakat, dan (iv) memberikan upah sebelum keringat buruh mengering. Keempat spirit DNA inilah yang menjamin berlangsungnya kelestarian usaha sekaligus ketentraman batin bagi setiap pelaku bisnis dihadapan Tuhannya dan antara sesama manusia dalam lingkungannya, dan daerahnya. Model inilah yang akan menjamin terpeliharanya kelestarian usaha sekaligus dengan lingkungan fisik dan sosial. Pemikiran dan kajian empirik seperti ini dirintis oleh Broen, Martin and Harris, Chris, 1994; Nijkamp( 2001).

\section{Implementasi Model}

\section{Pemetaan Karakter Bisnis}

Karakter bisnis seperti yang diidentifikasikan dalam DNA-artificial chromosom dipetakan di tiap wilayah pengembangan. Mengapa mereka berhasil sedangkan yang lain gagal. Apa kelemahannya? Dapatkah kelemahannya itu diatasi dengan segera?. Cukupkah ragam dan karakter dari kebijakan untuk itu? Ini semua dikaitkan dengan kendala pembangunan yang lima itu (soft, hard, organization, financial, dan ecological wares).

\section{Pemasaran Citra}

Memasarkan citra bisnis (marketing image) untuk suatu produk tertentu diukur menurut kelayakan usahanya. Syarat ini tidak boleh diganggu-gugat oleh yang berakad. Sekali mengubahnya, misalnya mark-up atas biaya, atau salah satu DNA chromosom diganti, maka bisnis akan gagal ditengah jalan. Dalam skenario CIAD antara doa dan kerja harus selaras dan serasi dan terjadi seketika dalam dimensi waktu, ruang dan energi (Sarkaniputra, 2002, 2003, 2004). Inilah yang merekam kecerdasan emosional, spiritual dan intelektual dari para pelaku bisnis, masyarakat, dan Negara. Resultannya ialah pada keragaman akal budi/human mind dari masyarakat yang berasosiasi dengan keragaman lingkungannya. Pendekatan yan'g mungkin dapat diterapkan ialah dari Zadeh, 2000, 2002a, 2002b.

Pemasaran melalui dakwah bil lisan dan dakwah bil hal akan menjamin sasaran dakwah akan lebih mengerti dan memahami tentang apa yang menjadi fokus pembicaraan (Sarkaniputra, 2002). Ini dikaitkan dengan potensi wilayah pengembangan, baik jumlah dan kualitas SDM maupun SDA nya.

Untuk dimaklumi oleh kalangan pebisnis bahwa ketika kebijakan pembangunan memprioritaskan usaha-usaha untuk memenuhi kebutuhan dasar maka peluang dan kemungkinan tumbuh dan berkembangnya usaha kecil dan menengah harus diutamakan ketimbang melayani usaha berskala besar dan raksasa. Mereka, yang besar dan raksasa, dibiarkan untuk mandiri karena mereka telah mendapatkan fasilitas selama lebih dari 30 tahun. Perlakuan yang sama dalam mekanisme pelayanan dalam rangka good governance adalah sufficient condition bagi semua aktor bisnis'di Republik ini.

\section{Penutup}

Membangun manusia Indonesia seutuhnya adalah membangun akal-budil human mind dari setiap warga bangsa. $\mathrm{Hu}$ - 
man mind inilah yang mencirikan kecerdasan emosional, spiritual dan intelektual yang sebarannya beragam dari satu daerah ke daerah lainnya. Dari kecerdasan masyarakat itu lahir karsa untuk membangun potensi ekonomi yang ditujukan untuk memenuhi kebutuhannya ubtuk mencapai ridha Allah.

Mekanisme investasi dapat didorong ketika karakter dari setiap akad muamalah mengikuti $D N A$-artificial chromosom yang didasarkan pada pertimbangan nilai-nilai agama di mana human mind hidup, tumbuh dan berkembang. Manusia Indonesia seutuhnya akan terbentuk, tumbuh dan berkembang dengan pendekatan ini. Mungkin inilah wawasan ekonomi etika ketika diterapkan dalam muamalah seharihari seperti apa yang dimaksudkan oleh Ace Partadiredja. Pemikiran yang sejiwa dengan Ace Partadiredja juga ada terdapat pada Sukadji Ranuwihardjo, Roekmono Markam, dan Mubyarto.

\section{Daftar Pustaka}

As-Syatibi, Abu Ishaq,. th., al-Muwafaqat $f i$ Ushul as-Syari'ah, jilid II. Riyadh: Maktabah Riyadh al Haditsah.

Bal, Frans and Peter Nijkamp. 2001. In search of valid results in a complex economic environment: The potential of meta-analysis and value transfer. European Journal of Operational Research 128 (2001): 364-384. ((HYPERLINK http://www.eslevier. com/locate/dsw)). Corresponding author: E-mail address: HYPERLINK mailto:pnijkamp@econ.vu.ni. Departement of Spatial Economics, Tinbergen Institute, Free University, De Boelelaan 1105, NL-1081 HV Amsterdam, Netherlands.
Broen, Martin and Harris, Chris, 1994, Neurofuzzy Adaptive Modelling and Control, UK: Prentice-Hall International.

Chapman, Chris and Stephen Ward. 2002. Managing Project Risk and Uncertainty. Inc. New York: John Willey \& Sons.

Chorafas, Dimitris N.1995. Chaos Theory in the Financial Markets. New Delhi: S. Chan.

Conner, Daryl R. 1998. Leading at the Edge of Chaos. New York: John Willey \& Sons, Inc.

Choudhury, Masudul Alam, 1986. Contribution to Islamic Economic Theory. St. New York: Martin's Press.

Choudhury, Masudul Alam, 1997. Money in Islam: A study in Islamic Political Economy. London and New York: Routledge.

Choudhury, Masudul Alam, 1998a. Study in Islamic Social Sciences. New York: St. Martin's Press.

Choudhury,MasudulAlam, 1998b. Reforming the Muslim World. London and New York: Kegan Paul International.

Kaplan, Robert S and David P. Norton, 2004. Strategy Maps. Boston, Massachusetts: Harvard Business School Press.

Klir, George J, and Folger, Tina A, 1995, Fuzzy Sets, Uncertainty, and Information, New Delhi: Prentice-Hall of India. 
Kosko, Bart, 1992, Neural Networks and Fuzzy Syastems : a Dynamical Systems Approach to Machine Intelligence, USA: Prentice-Hall International.

Kosko, Bart, 1992, Neural Networks and Fuzzy Syastems : a Dynamical Systems Approach to Machine Intelligence, USA: Prentice-Hall International.

Kosko, Bart, 1997, Fuzzy Engineering, USA: Prentice-Hall International Edition.

Markam, Roekmono, 1978, Menuju ke Definisi Ekonomi Post Robbins. Pidato Pengukuhan Jabatan Guru Besar dalam IImu Ekonomi pada Fakultas Ekonomi UGM, 19 September 1978, Yogyakarta.

Mubyarto, 1979, Gagasan dan Metode Berpikir Tokoh-tokoh Besar Eknonomi dan Penerapannya Bagi Kemajuan Kamanusiaan. Pidato Pengukuhan sebagai Guru Besar pada Fakultas Ekonomi UGM, 19

Nijkamp, Peter dan Hoyan Yim. 2001. Critical succes factors for offshore airports - a comparative evaluation. Journal of Air Transport Management 7 (2001): 181-188.

Nijkamp, Peter, 1979. Multidimensional Spatial Data and Decision Analysis. John Willey \& Sons, Chichester, New York, Brisbane, Toronto.

Partadiredja, Ace, 1981, Ekonomika Etik, Pidato Pengukuhan sebagai Guru Besar pada Fakultas Ekonomi UGM, 23 Mei 1981, Yogyakarta
Raniuwihardjo, Sukadji, 1973, Teori, Model dan Masalah Pembangunan Ekonomi, Pidato Pengukuhan Jabatan Guru Besar dalam IImu Ekonomi pada Fakultas Ekonomi UGM, 20 Agustus 1973, Yogyakarta.

Sarkaniputra, Murasa, 1983, Distribusi Pendapatan Fungsional di Sektor Pertanian dalam Ekonomi Indonesia 1975: Suatu Kajian Input-output a la Leontief-Sraffa, Draft Disertasi, Fakultas Ekonomi Universitas Gadjah Mada, Yogyakarta

Sarkaniputra, Murasa, 1986. Analisis InputOutput Sebagai Kerangka Strategi Pembangunan Pertanian. Disertasi Doktor pada Universitas Gadjah Mada, Yogyakarta, Indonesia.

Sarkaniputra, Murasa. 1999. Pengantar Ekonomi Islam. Bahan kuliah pada Fakultas Syari'ah IAIN Syarif Hidayatullah, Jakarta.

Sarkaniputra, Murasa. 2000. Produksi dan Distribusi Pendapatan Fungsional dalam Perspektif Ekonomi Islam. Fakultas Syari'ah IAIN Syarif Hidayatullah. Bahan diskusi untuk dosen Jurusan Muamalah, 4 November 2000 .

Sarkaniputra, Murasa, 2003. Hutanku, Hutanmu, Hutan Kita Semua, Bogor: Yayasan Bina Lingkungan Gunung Salak.

Sarkaniputra, Murasa, 2004. Adil dan Ihsan dalam Perspektif Ekonomi Islam:

Implementasi Mantik Rasa dalam Model Konfigurasi Teknologi al-Ghazali - as- 
Pembangunan Pertanian Berbasis Kecerdasan Masyarakat; H. Murasa Sarkaniputra

Syatibi - Leontif-Sraffa. Jurnal AlIqtishadiyah, P3EI UIN Syarif Hidayatullah Jakarta, Vol.I No. 1, Januari 2004.

Zadeh, Lotfi A, 2000. Toward the Concept of Generalized Definability. August 8, Helsinki, Finland.

Zadeh, LotfiA, 2002a. From Computing with Numbers to Computing with WordsFrom Manipulation of Measerements to Manipulation of Perceptions. Ber(BISC), Computer Science Division and the Electronoics Research Laboratory, Department of EECS, University of California, Berkeley, CA947201776, U.S.A.

Zadeh, LotfiA, 2002b. Toward a Perceptionbased Theory of Probabilistic Reasoning with Imprecise Probabilities. Journal of Statistical Planning and Inference. www.elsevier.com/locate/ jspi. 